\title{
Does the Pollyannaish View on Life Hold during Early COVID-19 Quarantine? Modeling the Effects of Positive Emotions, Hope, Optimism and Life Meaning on Life Satisfaction
}

\author{
Theodoros Kyriazos* ${ }^{\circledR}$, Michalis Galanakis, Ioannis Katerelos, Anastassios Stalikas \\ Department of Psychology, Panteion University, Athens, Greece \\ Email: *th.kyriazos@gmail.com
}

How to cite this paper: Kyriazos, T., Galanakis, M., Katerelos, I., \& Stalikas, A. (2021). Does the Pollyannaish View on Life Hold during Early COVID-19 Quarantine? Modeling the Effects of Positive Emotions, Hope, Optimism and Life Meaning on Life Satisfaction. Open Journal of Social Sciences, 9, 315-338.

https://doi.org/10.4236/jss.2021.910023

Received: September 7, 2021

Accepted: October 26, 2021

Published: October 29, 2021

Copyright $\odot 2021$ by author(s) and Scientific Research Publishing Inc. This work is licensed under the Creative Commons Attribution International License (CC BY 4.0).

http://creativecommons.org/licenses/by/4.0/

cc) (i) Open Access

\begin{abstract}
This study examined 1) the effects of positive emotions, hope, optimism, and life meaning, on life satisfaction during early COVID-19 quarantine; 2) the inter-relationships between hope, optimism, life meaning and positive emotions. Respondents (759 Greek adults from the general population) completed self-report measures of affectivity (SPANE-8), life satisfaction (SWLS), hope (AHS), life meaning (MLQ) and optimism (LOT-R). A Structural Equation Model (SEM) was specified. The measurement model showed good fit, model-based reliability, convergent/discriminant validity and strict measurement invariance across gender. The full SEM model had equally good fit. The effects of Positive Emotions, Presence of Life Meaning, Optimism and Hope Agency on Life Satisfaction were positive and significant, from $0.265-0.402$ (61.5\% explained variance). The effect of Positive Emotions on Hope Agency was not significant. The effects of Optimism and Presence of Life Meaning on Hope Agency were positive, significant and strong (0.484 - 0.764). The effects of Positive Emotions and Presence of Life Meaning on Optimism were positive, significant but weak. The effect of Positive Emotions on Presence of Life Meaning was positive, significant and strong. Some study limitations were the cross-sectional design, non-probability sampling, imbalanced sample regarding gender, single method of data collection. In conclusion, during COVID-19 early quarantine: 1) Positive Emotions, Hope Agency, Optimism and Presence of Life Meaning explained almost 2/3 of Life Satisfaction; 2) Optimism had the strongest positive effect on Hope Agency; 3) Positive Emotions had the second strongest positive effect on Presence of Life Meaning. Findings have implications for efforts to sustain and promote Life Satisfaction during and after COVID-19 context.
\end{abstract}




\section{Keywords}

COVID-19, Quarantine, Structural Equation Modeling (SEM), Positive

Emotions, Life Satisfaction, Hope, Optimism, Life Meaning

\section{Introduction}

WHO (2020) urged to magnify positive, hopeful stories of individuals with COVID-19. Positive emotions, hope, optimism and life meaning were associated with increased life satisfaction (Fredrickson, Cohn, Coffey, Pek, \& Finkel, 2008). This was labelled the Pollyannaish life outlook (Peterson \& Seligman, 2004).

The primary goal of this study was to investigate if during the early COVID-19 quarantine positive emotions, hope, optimism and life meaning could increase life satisfaction (Fredrickson et al., 2008). A secondary goal was to examine the inter-relationships between hope, optimism, life meaning and positive emotions during COVID-19.

\subsection{The Effect of Hope, Optimism, Life Meaning and Positive Emotions on Life Satisfaction (Primary Hypotheses)}

Life satisfaction (LS) is a global life judgement (Pavot, 2018) and a subjective well-being component (Diener, Suh, Lucas, \& Smith, 1999). Specifically, subjective well-being (SWB) includes affectivity, and cognitive life judgments (Diener et al., 1999).

Hope and optimism are distinct but related constructs, predicting LS (Bailey, Eng, Frisch, \& Snyder, 2007). Equally, positive emotions and life meaning are associated with LS and SWB, the ACT well-being model (Steger, Sheline, Merriman, \& Kashdan, 2013), and other well-being models (Emmons, 1986; Ryff, 1989).

\subsubsection{Positive Emotions}

Positive and negative emotions are short-term response tendencies (Lazarus, 1991), contributing to LS through broadened awareness (Fredrickson, 2001). Over time, broadened awareness may increase cognitive-psychological resources like hope, optimism and life meaning that in turn increase LS (Fredrickson, 2001).

Experimental work consistently found that increased positive emotions predicted LS (see Fredrickson, 2013). A study in students reported that positive emotions were more likely to predict LS the previous year than the opposite (Datu \& King, 2016). Positive emotions were associated with LS through hope agency in US adults (Chang et al., 2019) and in Chinese adults experiencing intimate partner violence (Li, Gu, Ma, Liu, \& Tang, 2021).

\subsubsection{Hope}

Hope emerges when expecting negative outcomes, boosting the intention to re- 
verse things (Fredrickson, 2013). This taps the bidimensional definition of hope (Snyder et al., 1991) referring to goal-setting (agency) and plans to achieve goals (pathways). Agency motivates reversion and pathways taps perceived ability to generate attainable goal trajectories (Snyder, 2000).

A meta-analysis on LS (Yarcheski \& Mahon, 2014), found hope had the largest mean effect from all variables associated with LS, including optimism. Hope predicted LS in adults from Spain during COVID-19 (Blasco-Belled, Tejada-Gallardo, Torrelles-Nadal, \& Alsinet, 2020). Hope, like optimism amplifies resources to overcome challenging situations, increasing LS (Bailey, Eng, Frisch, \& Snyder, 2007).

\subsubsection{Optimism}

Scheier and Carver (1985) define optimism a general expectation of favorable outcomes, mediating between the self and world interpretation (Carver, Scheier, \& Segerstrom, 2010). Optimism has a self-regulatory dimension based on goal achievement through the regulation of actions and behaviors, i.e. when in hardship while trying to achieve goals, optimists will probably continue trying, whereas pessimists will probably give up (Carver \& Scheier, 1998). Optimism has also an attributional dimension, explaining life events (Peterson \& Seligman, 2004).

Optimism had a moderate-high correlation to LS in Western samples (Scheier \& Carver, 1992). Optimism predicted LS through goal orientation in Spanish students (Supervía, Bordás, \& Lorente, 2020), or through self-esteem and relationship harmony in elderly from Hong Kong (Leung, Moneta, \& Mcbride-Chang, 2005), or partially through positive-negative emotions in Turkish students (Kapikiran, 2012).

\subsubsection{Life Meaning}

People perceive presence of life meaning when they comprehend themselves, the world, and their unique fit in the world, perceiving accomplishment (Steger, 2009a). Steger (2012) argues that this is the cognitive component of meaning (meaning comprehension), facilitating the motivational component of meaning (life purpose) which is also connected with goals like hope and optimism (Snyder, 2000). Search for meaning is another meaning component, negatively related to presence of meaning (Steger, Frazier, Oishi, \& Kale, 2006).

Steger et al. (2006) reported that presence of meaning is positively associated with LS. Experimental studies showed that those who perceive high presence of meaning have more LS than those who report low presence (Steger, 2009b). Additional studies also supported the association between presence of life meaning and LS (reviewed by Steger, 2012).

\subsection{The Inter-Relations between Hope, Optimism \& Life Meaning and Positive Emotions (Secondary Hypotheses)}

Hope and optimism involve goal-based cognitive processes when facing impor- 
tant outcomes (Snyder, Sympson, Michael, \& Cheavens, 2000). Although both signify relatively stable future expectations, they influence behaviors differently (Bailey et al., 2007). Snyder's (2000) hope model sets individuals the major force in determining desired outcomes, linking pathways and agency with the successful goal attainment, without emphasis on expectations, like optimism (Scheier \& Carver, 1985) but on agentic self-efficacy (Edwards, 2009; Gallagher, 2009). Snyder's model also distinguished hope from optimism, as conceptualized by Seligman (2006), in highlighting pursuit of specific goal-related outcomes (Snyder, 2000).

\subsubsection{The Effects of Positive Emotions, Optimism and Life Meaning on Hope}

Snyder et al. (1991) argue that emotions for a particular goal-related context are connected to hope. Although hope and optimism are closely associated, tapping motivation (Snyder, 2000), hope agency provides unique variance beyond optimism in predicting LS (Bailey et al., 2007; Edwards, 2009). Similarly, a meta-analysis suggested that optimism and hope were distinguishable, but both were associated with psychological well-being (Alarcon, Bowling, \& Khazon, 2013). Equally, life meaning was positively related to hope (Steger et al., 2006). Individuals who perceived more life meaning perceived higher levels of hope and this relationship was particularly strong for those who scored highly in agency (Cheavens \& Gum, 2000).

\subsubsection{The Effects of Positive Emotions and Life Meaning on Optimism} Several studies associated both meaning and positive emotions with optimism (Compton, Smith, Cornish, \& Qualls, 1996; Steger \& Frazier, 2005). Bronk, Hill, Lapsley, Talib, \& Finch (2009) found that youth perceiving higher meaning and purpose were more optimistic. Another study on Koreans elderly found that optimism was positively associated with life meaning, and the relationship between optimism and SWB was partially mediated by life meaning (Ju, Shin, Kim, Hyun, \& Park, 2013). Moreover, experimental settings testing the Broaden-and-Build theory (Fredrickson, 2001) argued that positive emotions increase optimism (Fredrickson et al., 2008).

\subsubsection{The Effects of Positive Emotions on Life Meaning}

Steger et al. (2006) reported that presence of life meaning was positively associated with positive emotions. Similarly, Fredrickson (2005) also proposed that life meaning and positive emotions go hand in hand. Experiments focusing on causal mechanisms of life meaning demonstrate that raising positive emotions is consequential to higher evaluations of life meaning (Steger, 2009b). Positive emotions helped resilient people find meaning amidst adversity (Tugade \& Fredrickson, 2004). King et al. (2006) also supported the effect of positive emotions on life meaning in adults from the U.S. in multiple studies. Similarly, positive emotions and meaning were reciprocally associated to one other in a longitudinal study on students from Hong Kong (Kwok \& Fang, 2021). 


\subsection{The Present Study}

In early COVID-19 outbreak, quarantined individuals limited socializing. Such measures controlled the spread of the virus (Greenstone \& Nigam, 2020) but threatened LS (Holmes et al., 2020). The ongoing research about the well-being of the quarantined individuals during the early COVID-19 stages showed somewhat conflicting findings. A longitudinal study that examined changes in subjective wellbeing in early stages of the COVID-19 pandemic in a German sample (Zacher \& Rudolph, 2021) showed that on average, life satisfaction, positive affect, and negative affect did not change significantly during these early stages. However, SWB decreased between March and May 2020 (Zacher \& Rudolph, 2021). A different longitudinal study on UK adults (O'Connor et al., 2020) showed that the mental health and well-being of the UK adult population appears to have been affected in the early phase of the COVID-19 pandemic. Suicidal ideation increased over time. Crucially, well-being also increased. Female respondents, youngsters, individuals from socially disadvantaged backgrounds and individuals with pre-existing mental health problems had worse mental health outcomes during the pandemic (O'Connor et al., 2020).

Therefore, this study focused on protective factors of LS during early COVID-19 quarantine context: 1) the effects of positive emotions, hope, optimism, life meaning, on the LS; 2) the inter-relationships between hope, optimism, life meaning and positive emotions. Specifically, the aim of the present study was to explore how the relevance of the quarantine condition, is connected to the life satisfaction of the quarantined individuals in relation to their emotions. Furthermore, we explored the outcome of emotions-in particular, the relationship between emotions and presence of life meaning, optimism and hope agency as well as between emotions and life satisfaction. In this way, more informed positive emotions interventions could be designed based on the broaden and build theory of positive emotions (Fredrickson, 2001), and tailored to sustain and increase the depleted well-being of the quarantined individuals (Holmes et al., 2020).

Accordingly, one primary hypothesis (H1) and three secondary hypotheses (H2-H4) were specified:

H1. Positive emotions, Presence of life meaning, Optimism and Hope Agency have a significant, direct positive effect on Life Satisfaction (paths H1a-H1d).

H2. Positive emotions, Optimism and Presence of life meaning have a significant, direct positive effect on Hope Agency (paths H2a-H2c).

H3. Positive emotions and Presence of life meaning have a significant, direct positive effect on Optimism (paths $H 3 a-H 3 b$ ).

H4. Positive emotions have a significant, direct positive effect on Presence of life meaning ( $p$ ath H4a).

A cross-sectional study design was implemented, processing data with Structural Equation Model (SEM). See the research model in Figure 1. 


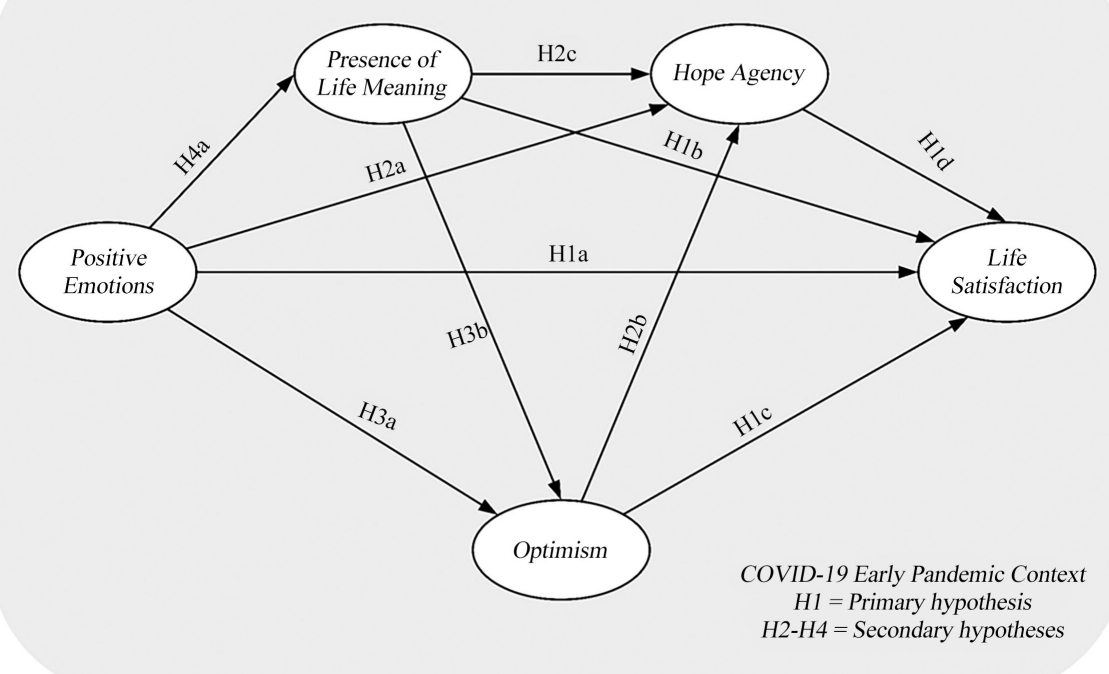

Figure 1. The hypotheses tested for each path of the research model.

\section{Methods}

\subsection{Participants \& Procedure}

The inclusion criteria were to be an adult of the general population, 18 - 75 years. The sample comprised 759 Greeks (78\% females). One in 4 respondents was 18 - 40 years, $42 \%$ was $41-60,3 \%$ was $61-70$ and $1 \%$ was $>70$ years. One in 2 respondents was single (47\%), married/living together (40\%), divorced/widowed (13\%). Most respondents (59\%) did not have children. Almost half respondents had a BA (42\%), or lower (13\%). The $41 \%$ had a MA or higher $(5 \%)$. There were 98.8\% non-COVID respondents. Participants were involved in this study with network sampling (APA, 2014). Data were collected online after obtaining inform consent. Participants did not receive any inducements. The study was available online from April, $5^{\text {th }}$ to May $4^{\text {th }}, 2020$. This sample was used before (Kyriazos, Galanakis, Karakasidou, \& Stalikas, 2021).

\subsection{Sample Power}

A priori power analysis of the SEM model with population RMSEA (MacCallum, Browne, \& Sugawara, 1996), indicated the required sample size was $N=212(<N$ $=759)$ for $80 \%$ power to reject a wrong model $(d f=179)$, RMSEA misspecification $=0.05$, alpha $=0.05$. See the a priori power analysis graph in Figure A1 (Appendix).

\subsection{Measures}

\subsubsection{Scale of Positive and Negative Experience 8 (SPANE-8)}

SPANE-8 (Diener et al., 2010; Kyriazos, Stalikas, Prassa, \& Yotsidi, 2018) is a briefer version of SPANE-12. Items are rated on a 5-point Likert scale ( $1=$ Very Rarely or Never to $5=$ Very Often or Always). Cronbach's alpha in the Greek 
population (Kyriazos, Stalikas, Prassa, \& Yotsidi, 2018) was 0.85 for SPANE-8 P (Positive), and 0.75 for SPANE-8 N (Negative).

\subsubsection{Satisfaction with Life Scale (SWLS)}

The SWLS (Diener, Emmons, Larsen, \& Griffin, 1985) measures perceived global life satisfaction (e.g. "I am satisfied with my life") on a 7-point scale, from 1 (Strongly Disagree) to 7 (Strongly Agree). Score ranges from 5 (Extremely dissatisfied) to 35 (Extremely satisfied). Diener et al. (1985) reported Cronbach's alpha was 0.87. In a Greek sample it was 0.88 (Kyriazos, Stalikas, Prassa, Galanakis, Flora, \& Chatzilia, 2018).

\subsubsection{Adult Trait Hope Scale (AHS)}

Adult Hope Scale (Snyder et al., 1991) is a self-report, 12-item measure of hope (e.g. "I can think of many ways to get out of a jam"), with two factors: Agency and Pathways. Items are rated on an 8-point Likert scale $(1=$ Definitely False, 8 $=$ Definitely True). Score ranges from 8 to 64 . Higher scores suggest greater hope. Snyder et al. (1991) reported Cronbach's alphas from $0.74-0.84$ and in a Greek sample it was 0.89 (Kyriazos, Stalikas, Prassa, Yotsidi, Galanakis, \& Pezirkianidis, 2018).

\subsubsection{Meaning in Life Questionnaire (MLQ)}

The MLQ (Steger et al., 2006) is a self-report, 10-item questionnaire of life meaning (e.g. "I have a good sense of what makes my life meaningful"), with five items tapping two factors (Presence of Meaning, Search for Meaning). Items are rated on a 7 -point Likert scale ( $1=$ Absolutely True to $7=$ Absolutely Untrue). Possible scores range from 5 ( $\min$ ) to 35 ( $\max$ ). Steger et al. (2006) reported Cronbach's alpha ranged from $0.81-0.86$ for Presence and $0.84-0.92$ for Search. For a Greek sample, Stalikas, Kyriazos, Yotsidi, \& Prassa (2018) reported $\alpha=0.85$ for the Presence and 0.86 for the Search.

\subsubsection{Life Orientation Test (LOT-R)}

The LOT-R (Scheier, Carver, \& Bridges, 1994) is a self-report, 10-item measure of optimistic/pessimistic life-expectations. Three items are positively worded (e.g. "In uncertain times, I usually expect the best"), and three negatively (plus 4 fillers). Respondents rate items on a 5 -point Likert scale $(0=$ Strongly Disagree, 4 = Strongly Agree). Alpha coefficient was 0.78 (Scheier et al., 1994).

\subsection{Data Analysis}

\section{Data Diagnostics}

A priori power analysis evaluated sample size adequacy of the full SEM model with the population RMSEA method (MacCallum, Browne, \& Sugawara, 1996). There was no missing data processing because the online form had all the fields set as "required" to minimize non-response (Kyriazos, 2018a). Outliers were detected separately for each study measure and for the SEM measurement model using Mahalanobis distance criterion. Multivariate nor- 
mality of all scale scores and of the measurement model was examined with multiple tests.

\section{Analytic Strategy}

Initially, a CFA confirmed the factor structure of SPANE-8, MLQ, AHS, LOT-R and SWLS separately, to ensure that their hypothesized structure was tenable in this quarantined Greek sample (essentially a special population). Note also that LOT-R structure was unverified in Greece. Model fit criteria at all instances were RMSEA [90\% CI $\leq 0.06] \leq 0.06$, SRMR $\leq 0.08$, CFI $\geq 0.95$, TLI $\geq$ 0.95 (Hu \& Bentler, 1999). Internal consistency reliability of all measures was at this stage evaluated with Cronbach's alpha $[95 \% \mathrm{CI}]$ and the greatest-lower-bound estimate of reliability (glb; Jackson \& Agunwamba, 1977) to account for the absence of the factorial structure in Cronbach's alpha calculation (DeVellis, 2017). It holds that $g l b \geq$ alpha (see Mair, 2018).

Next, a Structural Equation Model (SEM) was specified to test the study's main hypotheses adopting the two-Step Approach. The SEM measurement and the full SEM model were estimated with a robust estimator (MLR) to correct the chi-square and standard errors for non-normality. The fit of the measurement model was tested to eliminate the possibility of misspecifications. Reliability of each measured variable was also examined (indicator reliability) to reject the likelihood that the exogenous constructs of the measurement model are redundant or they have a serious multicollinearity problem.

Subsequently, model-based reliability, and model-based convergent/discriminant validity for the latent variables in the measurement model was also examined with Composite Reliability (CR; Werts, Linn, \& Joreskog, 1974; $\omega$ coefficient; McDonald, 1999), Average Variance Extracted (AVE; Fornell \& Larcker, 1981), Maximum Shared Variance (MSV) and Average Shared Variance (ASV). Then, to cross-validate model-based discriminant validity for the measurement model two additional methods were calculated, namely the Fornell \& Larcker (1981) criterion and the Heterotrait-Monotrait (HTMT) ratio of correlation Method (Henseler, Ringle, \& Sarstedt, 2015). The Fornell-Lacker (1981) criterion compares the square root of the average variance extracted (AVE) with the correlation of latent constructs (Hair, Hult, Ringle, \& Sarstedt, 2014). The HTMT Ratio of Correlation Method involves comparing HTMT to a predefined threshold. A threshold of .85 was used here (Kline, 2011). The HTMT ratio of correlation Method was reported to achieve higher specificity and sensitivity compared to the Fornell-Lacker method (Henseler et al., 2015; Hamid, Sami, \& Sidek, 2017). Full measurement invariance of the SEM measurement model was also tested to evaluate if the measurement model has invariant factors, factor loadings, intercepts, and residuals across male and female respondents. Subsequently, the full SEM model fit was examined. Post hoc power analysis evaluated the sample size adequacy of the full SEM model with the population RMSEA method (MacCallum, Browne, \& Sugawara, 1996), to estimate the sample required for achieving a power of $80 \%$ to reject a wrong model. An al- 
pha level of 0.05 was assumed with an RMSEA misspecification of 0.05 (MacCallum et al., 1996; see Kline, 2016). After confirming that the SEM model was robust, and it showed adequate model-based convergent-discriminant validity, satisfactory model-based reliability and measurement invariance Hypothesis testing followed (H1-H4). Ten direct paths were specified. Table 1 lists the analysis steps, implemented with $\mathrm{R}$ software ( $\mathrm{R}$ Development Core Team, 2021).

\section{Results}

\subsection{Preliminary Analysis}

There were no missing values because all fields of the online survey were set as required to eliminate non-response (Stalikas \& Kyriazos, 2019). Multivariate normality tests $(p<0.001)$ and data screening for outliers (Table A1 in the Appendix) were carried out for each measure separately and for the measurement model. Outliers were correct data entries, not impairing findings, final $N=759$.

Table 1. Analytic strategy.

\begin{tabular}{|c|c|c|}
\hline $\begin{array}{l}\text { Analysis } \\
\text { Sequence }\end{array}$ & Description & Rationale \\
\hline 1 & Data screening & To detect Outliers with Mahalanobis distance control. \\
\hline 2 & $\begin{array}{l}\text { Multivariate Normality Test with Multiple } \\
\text { tests }\end{array}$ & $\begin{array}{l}\text { To test the multivariate normality assumption with Mardia's multivariate kurtosis and } \\
\text { multivariate skewness test, Henze-Zirkler's consistent test, Doornik-Hansen omnibus test, } \\
\text { and Energy test. }\end{array}$ \\
\hline 3 & $\begin{array}{l}\text { Confirmatory Factor Analysis (CFA) of the } \\
\text { study measures }\end{array}$ & To confirm structure in this sample. \\
\hline 4 & Descriptive Statistics & $\begin{array}{l}\text { To calculate means, medians, standard deviations, and reliability coefficients } \\
\text { (see Kyriazos, 2017), i.e. alpha and greatest lower bound estimate (glb; Jackson \& } \\
\text { Agunwamba, 1977) for the latent variables of the measurement model. It holds glb } \geq \alpha \\
\text { (Mair, 2018). }\end{array}$ \\
\hline 5 & $\begin{array}{l}\text { Test the SEM measurement model fit and } \\
\text { indicator reliability }\end{array}$ & $\begin{array}{l}\text { To evaluate the fit of the measurement model since four out of five measures were } \\
\text { partially used. Reliability of the observed variables was evaluated to reject the likelihood } \\
\text { that the exogenous constructs are redundant or they have a multicollinearity problem. }\end{array}$ \\
\hline 6 & $\begin{array}{l}\text { Model-based Reliability and Validity } \\
\text { Analysis of the latent variables in the } \\
\text { measurement model }\end{array}$ & $\begin{array}{l}\text { To evaluate the Composite Reliability (CR; Werts, Linn, \& Joreskog, 1974; } \omega \text { coefficient; } \\
\text { McDonald, 1999) and Average Variance Extracted (AVE; Fornell \& Larcker, 1981), } \\
\text { Maximum Shared Variance (MSV) and Average Shared Variance (ASV), evidencing } \\
\text { model-based convergent and discriminant validity. }\end{array}$ \\
\hline 7 & $\begin{array}{l}\text { Cross-validating model-based Discriminant } \\
\text { Validity with additional methods }\end{array}$ & $\begin{array}{l}\text { To cross-validate model-based discriminant validity with the Fornell \& Larcker (1981) } \\
\text { criterion and the HTMT Ratio of Correlation Method (Henseler, Ringle, \& Sarstedt, 2015). }\end{array}$ \\
\hline 8 & $\begin{array}{l}\text { Full measurement invariance of the SEM } \\
\text { measurement model }\end{array}$ & $\begin{array}{l}\text { To test if the measurement model has invariant factors, factor loadings, intercepts, and } \\
\text { residuals across gender. }\end{array}$ \\
\hline 10 & $\begin{array}{l}\text { A priori \& post hoc power analysis of the full } \\
\text { SEM model with the RMSEA }\end{array}$ & $\begin{array}{l}1 \text { To evaluate the sample required for } 80 \% \text { power to reject a wrong model. An alpha level of } \\
0.05 \text { was assumed with RMSEA misspecification } 0.05 \text { (MacCallum et al., 1996). }\end{array}$ \\
\hline 11 & Hypotheses testing (H1-H4) & Ten direct paths were specified. \\
\hline
\end{tabular}


Subsequently, a CFA verified the factor structure of each measure (see Table A2 in the Appendix). A two-factor structure was supported for SPANE-8 (Diener et al., 2010; Kyriazos, Stalikas, Prassa, \& Yotsidi, 2018), MLQ (Steger et al., 2006), AHS (Snyder et al., 1991) and LOT-R (Bailey et al., 2007) and SWLS was unifactorial (Diener et al., 1985). Despite the marginal RMSEA fit for some measures (see Kyriazos, 2018a), adding error covariances or omitting items to improve fit was deemed premature, before evaluating the SEM measurement model.

\subsection{Descriptive Statistics}

All correlation coefficients $(p<0.001)$, means, medians, standard deviations, and reliability coefficients for the latent variables of the measurement model are shown in Table 2. The latent variables of the measurement model were SPANE-8 P (Positive), MLQ-P (Presence), AHS-A (Agency), LOT-R O (Optimism) and SWLS.

\subsection{Measurement Model}

The measurement model to test the relationship of positive emotions, presence of life meaning, hope agency, optimism and life satisfaction fitted the data well, $\chi^{2}(179)=439.352(p=0.000), \mathrm{CFI}=0.960, \mathrm{TLI}=0.953, \mathrm{RMSEA}=0.044[90 \% \mathrm{CI}$ $=0.039,0.048], \mathrm{SRMR}=0.041$ (MLR estimator). All standardized factor loadings (Table A3 in the Appendix), stayed well above the 0.40 threshold (Brown, 2015), from 0.597 to $0.901, p<0.001$. The $\mathrm{R}^{2}$ ranged from 0.137 to 0.777 , i.e. latent variables accounted for a variance from $36 \%$ to $81 \%$ by each observed variable (Table A3 in the Appendix). Inter-factor correlations varied between 0.404 and 0.699. The factor loadings of all observed variables were higher on their assigned latent variable, suggesting reliability for the observed variables.

Table 2. Correlation coefficients (Spearman's rho), means, medians, standard deviations, and reliability for the measurement model variables $(N=759)$.

\begin{tabular}{|c|c|c|c|c|c|c|c|}
\hline $\begin{array}{c}\text { Latent Variable of the Measurement } \\
\text { Model }\end{array}$ & $\alpha[95 \% C I]$ & $g l b$ & 1 & 2 & 3 & 4 & 5 \\
\hline 1. Positive emotions & $0.88[0.87,0.89]$ & 0.89 & - & & & & \\
\hline 2. Presence of life meaning & $0.90[0.89,0.91]$ & 0.91 & $0.38^{* *}$ & - & & & \\
\hline 3. Optimism & $0.70[0.66,0.73]$ & 0.72 & $0.40^{* *}$ & $0.47^{* *}$ & - & & \\
\hline 4. Hope Agency & $0.83[0.81,0.85]$ & 0.86 & $0.36^{* *}$ & $0.59^{* *}$ & $0.51^{* *}$ & - & \\
\hline 5. Life satisfaction & $0.87[0.85,0.88]$ & 0.89 & $0.49^{* *}$ & $0.59^{* *}$ & $0.48^{* *}$ & $0.55^{* *}$ & - \\
\hline$M$ & - & - & 12.95 & 5.26 & 8.83 & 24.68 & 24.07 \\
\hline$S D$ & - & - & 3.36 & 1.17 & 2.3 & 4.49 & 5.69 \\
\hline Median & - & - & 13 & 5.4 & 9 & 25 & 25 \\
\hline
\end{tabular}

${ }^{* *} p<0.001$. Note. $\mathrm{CI}=$ Confidence Intervals, $g l b=$ greatest lower bound, Positive emotions $=$ SPANE- 8 P, Presence of life meaning $=\mathrm{MLQ}-\mathrm{P}$, Optimism $=$ LOT-R O, Hope Agency = AHS-A, Life satisfaction $=$ SWLS. 


\subsubsection{Measurement Model Reliability, Convergent and Discriminant Validity}

Model-based, internal consistency reliability and convergent validity were adequate (Hair, Black, Babin, \& Anderson, 2010), measured by Composite Reliability (CR; Werts et al., 1974) and AVE respectively (AVE; Fornell \& Larcker, 1981). Specifically, CR ( $\omega$ coefficient; McDonald, 1999), ranged from 0.77 (LOT-R O) to 0.89 (MLQ-P) and AVE ranged from 0.54 (LOT-R O) to 0.65 (SPANE-8 P); see Table 3. Measurement model latent variables were sufficiently different, as indicated by Maximum Shared Variance and Average Shared Variance (MSV; ASV; Fornell \& Larcker, 1981) in comparison to AVE. Furthermore, by implementing the Fornell \& Larcker (1981) criterion the square root of AVE for each latent variable in the measurement model (Table 3 diagonals in bold) was compared to the maximum correlation between all the latent variables (Table 3, below-diagonal highlighted cells), also suggesting that the latent variables were sufficiently different. Finally, discriminant validity was cross-validated with the Heterotrait-Monotrait (HTMT) ratio of correlation adopting the calculation proposed by Henseler et al. (2015). Implementing the $\mathrm{HTMT}_{0.85}$ threshold (Hamid, Sami, \& Sidek, 2017), the latent variables of the measurement model differed adequately (Table 3, above-diagonal highlighted cells). For the Internal consistency reliability (Cronbach's alpha and $g l b$ ) of all measures in the measurement model, see Table 2.

\subsubsection{Measurement Model Invariance}

The invariance of the measurement model was evaluated across gender $\left(n_{\text {MALES }}=\right.$ $170, n_{\text {FEMALES }}=589$ ). The difference test thresholds were $|\Delta \mathrm{CFI}|<0.01$ (Cheung \& Rensvold, 2002), and $\mid \Delta$ RMSEA $\mid<0.01, N=759>300$ (Chen, 2007: p. 501). The model showed a good fit for males, $\chi^{2}(179)=270.6779, p=0.000$, CFI $=$ 0.952 , TLI $=0.943$, RMSEA $=0.055[90 \% \mathrm{CI}=0.043,0.066]$, SRMR $=0.055$ and equally good for females, $\chi^{2}(179)=448.538, p=0.000$, CFI $=0.951$, TLI $=0.942$, RMSEA $=0.051[90 \% \mathrm{CI}=0.045,0.056]$, SRMR $=0.048$. The configural structure was verified (Model 1 , Table 4 ). $\triangle$ CFI and $\triangle$ RMSEA consecutively suggested full weak, strong and strict invariance (Models 2-4, Table 4).

\subsection{Full SEM Model}

The full SEM model to study the relationship between positive emotions (SPANE-8 P), presence of life meaning (MLQ-P), optimism (LOT-R) O, Hope Agency (AHS-A) and life satisfaction (SWLS) during the COVID-19 containment measures showed a good fit to the data, $\chi^{2}(179)=439.319, p=0.000$, CFI $=0.960, \mathrm{TLI}=0.953, \mathrm{RMSEA}=0.044[90 \% \mathrm{CI}=0.039,0.048], \mathrm{SRMR}=0.041$. Post hoc power analysis based on population the RMSEA of the full SEM model (MacCallum et al., 1996) suggested that a sample size of $N=759$ was related to a power $>99.99 \%$ to reject a wrong model, $d f=179$, RMSEA $=0.05$ on alpha $=$ 0.05 (see Kline, 2016). Figure A1 in the Appendix presents graphs for a priori (see method section) and post hoc power analysis. 
Table 3. Estimates of model-based reliability, model-based convergent and discriminant validity for the measurement model with the Fornell \& Larcker (1981) method (highlighted cells below diagonal) and the HTMT ratio of correlation method (highlighted cells above diagonal), $N=759$.

\begin{tabular}{|c|c|c|c|c|c|c|c|c|c|}
\hline \multirow{2}{*}{$\begin{array}{c}\text { Latent } \\
\text { Variables }\end{array}$} & \multirow{2}{*}{$\mathrm{CR}(\omega)$} & \multirow{2}{*}{ AVE } & \multirow{2}{*}{ MSV } & \multirow{2}{*}{ ASV } & \multicolumn{5}{|c|}{ Latent Variables } \\
\hline & & & & & 1 & 2 & 3 & 4 & 5 \\
\hline 1. SPANE-8 P & 0.88 & 0.65 & 0.32 & 0.22 & 0.81 & 0.41 & 0.40 & 0.48 & 0.56 \\
\hline 2. MLQ-P & 0.89 & 0.61 & 0.49 & 0.36 & 0.40 & 0.78 & 0.70 & 0.60 & 0.68 \\
\hline 4. LOT-R O & 0.77 & 0.54 & 0.45 & 0.35 & 0.48 & 0.58 & 0.67 & 0.73 & 0.63 \\
\hline 5. SWLS & 0.87 & 0.57 & 0.47 & 0.40 & 0.57 & 0.67 & 0.69 & 0.61 & 0.75 \\
\hline
\end{tabular}

Note. Diagonals (in bold typeface) $=\sqrt{ }$ AVE, $C R=$ Composite Reliability ( $\omega$, McDonald, 1999), AVE = Average Variance Extracted, MSV = Maximum Shared Variance, ASV = Average Shared Variance. 1) Convergent Validity: CR > AVE $\geq 0.50$. 2) Discriminant Validity: MSV < AVE; ASV < AVE and $\sqrt{ }$ AVE > inter-item correlations. 3) Correlations for the Fornell \& Larcker (1981) Method are in highlighted cells below diagonal and 4) HTMT: Heterotrait-Monotrait correlation ratio. HTMT values are in highlighted cells above diagonal.

Table 4. Goodness-of-Fit for the nested models to test full measurement invariance across gender for the SEM measurement model $(N=759)$.

\begin{tabular}{|c|c|c|c|c|c|c|c|}
\hline \multirow{2}{*}{ Nested Models } & \multirow{2}{*}{$x^{2}$} & \multirow{2}{*}{$d f$} & \multirow{2}{*}{ CFI } & \multirow{2}{*}{ RMSEA } & \multirow{2}{*}{ Model Comparison } & \multicolumn{2}{|c|}{ Difference in Fit } \\
\hline & & & & & & $\Delta \mathrm{CFI}$ & $\triangle \mathrm{RMSEA}$ \\
\hline Model 1. Configural Inv. & 716.61 & 358 & 0.947 & 0.051 & - & - & - \\
\hline Model 2. Full Weak Inv. & 741.32 & 374 & 0.946 & 0.051 & Model 2 vs 1 & -0.001 & 0.000 \\
\hline Model 3. Full Strong Inv. & 768.47 & 390 & 0.944 & 0.051 & Model 3 vs 2 & -0.002 & 0.000 \\
\hline Model 4. Full Strict Inv. & 789.03 & 411 & 0.944 & 0.049 & Model 4 vs 3 & 0.000 & -0.002 \\
\hline
\end{tabular}

Note. Estimator $=$ MLR.

\subsubsection{Hypotheses Testing ( $\mathrm{H} 1-\mathrm{H} 4)$}

The structural results for the relationship between positive emotions (SPANE-8 P), presence of life meaning (MLQ-P), optimism (LOT-R), Hope Agency (AHS-A) and life satisfaction (SWLS) during the COVID-19 containment measures are presented in Table 5 (path coefficients and their 95\% CI) and in Figure 2 (structural model). The path diagram of the full SEM model along with all the measurement models is presented in the Appendix (Figure A2).

All path coefficients were estimated both with the constrained and unconstrained error variance (Table 5). Parameter estimates and their standard errors were nearly identical to alternative estimations, suggesting robustness. Nine out of 10 direct standardized path coefficients tested (Table 5) showed statistically significant positive effects, $p<0.001$ and $p=0.044$ (H1c). The effect of Positive Emotions on Hope Agency (H2a) was not significant. Positive emotions, presence of life meaning, optimism and hope agency accounted for $61.5 \%$ of the variance in life satisfaction. The accounted variance for all latent variables in the model is presented in Figure 2 (structural model). 
Table 5. Structural results for the proposed full SEM model $(N=759)$.

\begin{tabular}{|c|c|c|c|c|c|c|c|c|c|}
\hline \multirow{2}{*}{ H path } & \multirow{2}{*}{ Path Description } & \multirow{2}{*}{ B } & \multirow{2}{*}{$\beta$} & \multicolumn{2}{|c|}{$95 \% \mathrm{CI}$} & \multirow{2}{*}{ SE } & \multirow{2}{*}{$\mathrm{z}$} & \multirow{2}{*}{$p$} & \multirow{2}{*}{$\mathrm{S} / \mathrm{R}$} \\
\hline & & & & LL & UL & & & & \\
\hline H1a & Positive Emotions $\rightarrow$ Life Satisfaction & 0.277 & 0.402 & 0.280 & 0.524 & 0.062 & 6.480 & 0.000 & S \\
\hline $\mathrm{H} 1 \mathrm{~b}$ & Presence of Life Meaning $\rightarrow$ Life Satisfaction & 0.263 & 0.305 & 0.169 & 0.440 & 0.069 & 4.415 & 0.000 & S \\
\hline $\mathrm{H} 1 \mathrm{c}$ & Optimism $\rightarrow$ Life Satisfaction & 0.123 & 0.265 & 0.007 & 0.523 & 0.132 & 2.013 & 0.044 & S \\
\hline H1d & Hope Agency $\rightarrow$ Life Satisfaction & 0.306 & 0.337 & 0.155 & 0.518 & 0.093 & 3.634 & 0.000 & S \\
\hline $\mathrm{H} 2 \mathrm{a}$ & Positive Emotions $\rightarrow$ Hope Agency & 0.034 & 0.045 & -0.059 & 0.149 & 0.053 & 0.841 & 0.400 & $\mathrm{R}$ \\
\hline $\mathrm{H} 2 \mathrm{~b}$ & Optimism $\rightarrow$ Hope Agency & 0.391 & 0.764 & 0.533 & 0.996 & 0.118 & 6.474 & 0.000 & S \\
\hline $\mathrm{H} 2 \mathrm{c}$ & Presence of Life Meaning $\rightarrow$ Hope Agency & 0.459 & 0.484 & 0.368 & 0.601 & 0.059 & 8.140 & 0.000 & S \\
\hline $\mathrm{H} 3 \mathrm{a}$ & Positive Emotions $\rightarrow$ Optimism & 0.292 & 0.197 & 0.132 & 0.262 & 0.033 & 5.948 & 0.000 & S \\
\hline $\mathrm{H} 3 \mathrm{~b}$ & Presence of Life Meaning $\rightarrow$ Optimism & 0.461 & 0.248 & 0.188 & 0.309 & 0.031 & 8.006 & 0.000 & S \\
\hline $\mathrm{H} 4 \mathrm{a}$ & Positive Emotions $\rightarrow$ Presence of Life Meaning & 0.404 & 0.507 & 0.391 & 0.623 & 0.059 & 8.583 & 0.000 & S \\
\hline
\end{tabular}

Note. Estimator $=$ MLR. $\mathrm{LL}=$ Lower Limit, $\mathrm{UL}=$ Upper limit, $\mathrm{H}=$ Hypothesis, $\mathrm{S}=$ Hypothesis Supported, $\mathrm{R}=$ Hypothesis Rejected. Positive emotions = SPANE-8 P, Presence of life meaning $=$ MLQ-P, Optimism $=$ LOT-R O, Hope Agency $=$ AHS - A, Life satisfaction $=$ SWLS.

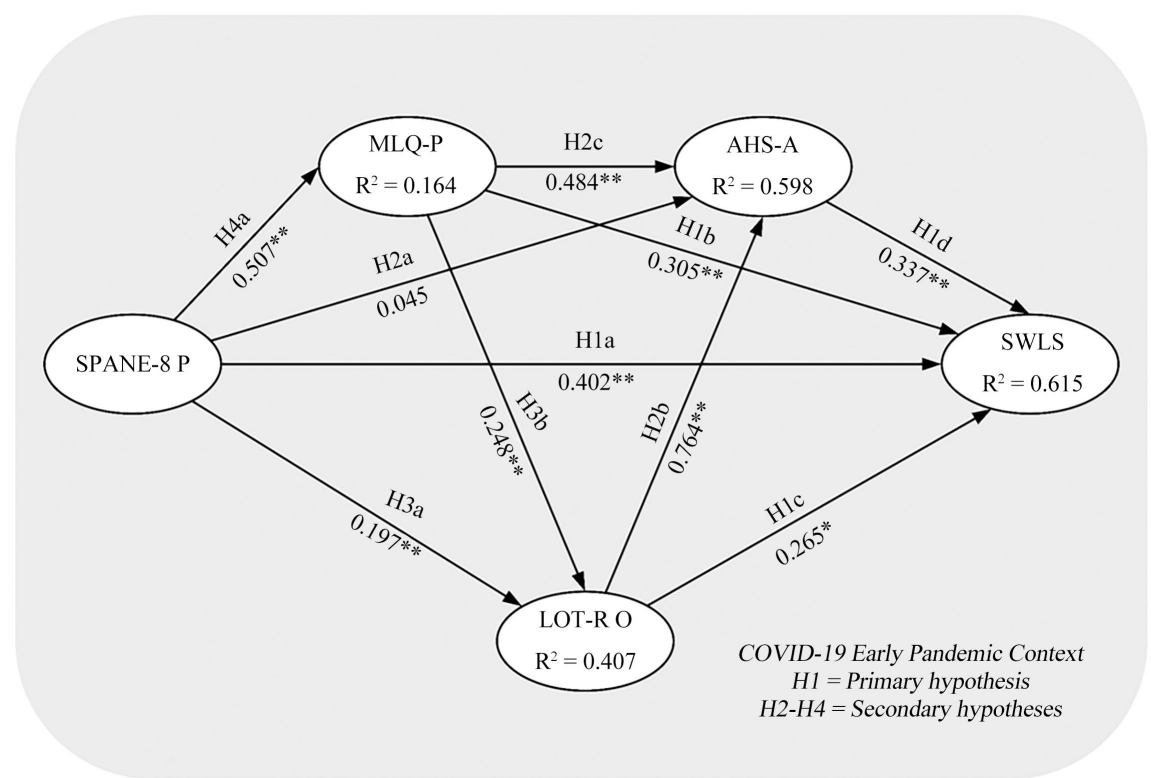

Figure 2. The path diagram of the structural model (direct standardized path coefficients, $\left.{ }^{\star} p<0.05,{ }^{* *} p<0.001\right)$. Note. SPANE-8 P = Positive emotions, MLQ-P = Presence of life meaning, LOT-R O = Optimism, AHS-A = Hope Agency, SWLS = Life satisfaction.

\section{Discussion}

In the early COVID-19 outbreak, quarantined individuals limited socializing. Containment measures controlled the spread of the virus (Greenstone \& Nigam, 2020) but depleted LS (Holmes et al., 2020). This study focused on examining protective factors for the depleted LS of the quarantined individuals based on the Pollyannaish life outlook amidst the early COVID-19 context, i.e. 1) the positive effects of positive emotions, hope, optimism, life meaning, on LS, during the early 
COVID-19 quarantine (primary hypothesis); 2) the positive inter-relationships between hope, optimism, life meaning and positive emotions during the quarantine (secondary hypotheses).

\subsection{Support of the Hypotheses}

The four primary hypothesis paths about the effects of positive emotions, hope agency, optimism and presence of life meaning on LS were supported. From the six secondary hypothesis paths about the positive inter-relation between positive emotions, hope agency, optimism and presence of life meaning, five were supported (Optimism $\rightarrow$ Hope Agency, Presence of Life Meaning $\rightarrow$ Hope Agency, Positive Emotions $\rightarrow$ Optimism, Presence of Life Meaning $\rightarrow$ Optimism, Positive Emotions $\rightarrow$ Presence of Life Meaning) and one was rejected (Positive Emotions $\rightarrow$ Hope Agency).

\subsection{Interpretation}

About the magnitude of the effects on LS, they suggested that increased positive emotions predicted a significant, moderately high increase in LS. An increase in presence of life meaning predicted a significant moderate increase in LS. Increased optimism predicted a low, marginally significant increase in LS. Increased hope agency moderately and significantly increased LS.

About the magnitude of the effects on hope agency, optimism and presence of life meaning, they suggested that increased positive emotions did not predict an increased hope agency. In contrast, increased optimism predicted a significant, very high increased hope agency. Increase in presence of life meaning predicted a significant, moderate to high increase in hope agency. Increase in positive emotions predicted a significant, small increase in optimism. Likewise, increase in presence of life meaning predicted a significant, low to moderate increase in optimism. Finally, positive emotions predicted a significant, high increase in presence of life meaning.

\subsection{Similarity of Results}

The positive relationships of positive emotions, hope, optimism and life meaning with LS were well-documented in literature. The positive effect of hope on LS was well supported before COVID-19 (Hirschi, Abessolo, \& Froidevaux, 2015) and during COVID-19 (Blasco-Belled et al., 2020). Pallini et al. (2018) proposed that time-perspective dimensions predicted LS through hope in Italian adolescents. LS in elderly samples was associated with high hope levels in later life (Cheavens \& Gum, 2000; Oliver, Tomás, \& Montoro-Rodriguez, 2017).

Moreover, the effect of positive emotions on LS was strong, supporting that positive emotions are major components of subjective well-being (Diener et al., 1999). Similarly, optimism was reported to have moderate to high correlations to LS in Western samples (Scheier \& Carver, 1992). In a similar vein, the magnitude of optimism and hope on LS was found low to moderate to other studies 
(Bailey et al., 2007). Finally, several studies also supported the association between presence of life meaning and LS before COVID-19 (Steger, 2012) and during COVID-19 (Arslan, Yıldırım, Karataş, Kabasakal, \& Kılınç, 2020; Yildirim \& Arslan, 2021).

The effects of optimism and life meaning on hope are well documented by a large body of research. Within the COVID-19 context, hope was positively related to life meaning and LS (Trzebiński, Cabański, \& Czarnecka, 2020). Beyond COVID-19, individuals who perceived more life meaning perceived higher levels of hope (Cheavens \& Gum, 2000; Feldman \& Snyder, 1999) and this relationship was particularly strong for those who scored highly in agency (Cheavens \& Gum, 2000). Similarly, the particularly strong association of optimism to hope agency (the strongest association of the present study), was supported by a meta-analysis suggesting that optimism and hope were strongly related but distinguishable from each other (Alarcon et al., 2013). In contrast, the insignificant relationship of positive emotions with hope agency despite the significant relationship of positive emotions with LS was also reported by Fredrickson et al. (2008) in an experimental, longitudinal study processed with latent growth models. She argued that maybe hope agency receives a consequential influence by change in positive emotions.

The effects of positive emotions and life meaning on optimism were also widely reported (Steger, 2012). Note however, that Fredrickson et al. (2008) also reported a similar pattern for optimism which may partially support the very low magnitude of the effect of positive emotions on optimism in this study.

Finally, on the large effects of positive emotions on life meaning experiments focusing on causal mechanisms of life meaning demonstrate that increased positive emotions are consequential to higher presence of life meaning (Steger, 2009b). Moreover, a longitudinal study showed that positive emotions could predispose perceived life meaning, increasing sensitivity to situation-specific life meaning (King et al., 2006). Indeed, increased positive emotions predicted the second largest increase in life meaning in this study.

\subsection{Generalizability, Limitations, Implications}

The statistical validity of the findings and sample size permit a relatively safe generalizability of the results. That is good model fit, highly significant effects, model-based reliability, convergent and discriminant validity.

Interpretation of the findings however should be cautious because of the non-probability sampling, and the cross-sectional design. The cross-sectional design disallows causal inferences. However, such rigid causality assumptions seem over-simplified with SEM (Kline, 2020).

One of the study limitations was the imbalanced sample in terms of gender. Additionally, some COVID-related demographics were somewhat underrepresented due to the limited and short-lived COVID-19 exposure of the general population during the early COVID-19 quarantine in Greece. Another limita- 
tion was that the study took place after the start of the early quarantine period, and initial response (if any) may be unrecorded. Moreover, the sample comprised only individuals with internet access and digital skills. Data was collected with a single method, using only self-report measures of health-related behaviors and well-being (see Pavot, 2018 for well-being measurement issues). The sample was also monocultural.

When the pandemic will be over, depleted LS could be the focus of health professionals (Fiorillo \& Gorwood, 2020). Therefore, this was an attempt to examine if well-established LS promoters and sustainers could be effective during and after COVID-19 context. Crucially, during early COVID-19 quarantine context, 1) positive emotions, hope agency, optimism and presence of life meaning explained almost $2 / 3$ of LS; 2 ) optimism had the highest positive effect on hope agency; 3 ) positive emotions had the second highest positive effect on life meaning.

The current pandemic altered the mental health agenda (Fiorillo \& Gorwood, 2020). Mental health professionals eventually have to address the impact of the pandemic as extreme stressors could induce or aggravate mental health issues (Holmes et al., 2020). Therefore, this is an attempt to model protective factors against COVID-19, potentially offering more tools from the positive psychology realm for the applied COVID-19 research, to build effective interventions that can boost well-being. Hopefully, this study contributes to the literature on affective factors during quarantine, a topic that is currently in the center of psychology research. Findings have implications for efforts to sustain and promote depleted Life Satisfaction during and after COVID-19 distressful context. Findings have implications for efforts to sustain and promote depleted Life Satisfaction during and after COVID-19 distressful context.

Future research on LS and cognitive-psychological resources during COVID-19 could study different contexts like workplace, or parenting (for Greece see Kyriazos \& Stalikas, 2018; Kyriazos \& Stalikas, 2019a; Kyriazos \& Stalikas, 2019b). Alternatively, except SEM other multivariate technique could shed light on the complex relationships of psychological distress and COVID-19 comorbidities (Holmes et al., 2020) like CFA Multitrait-Multimethod Matrices (see Kyriazos, 2018b) or Multilevel Modeling (see Kyriazos, 2019).

\section{Conflicts of Interest}

The authors declare no conflicts of interest regarding the publication of this paper.

\section{References}

Alarcon, G. M., Bowling, N. A., \& Khazon, S. (2013). Great Expectations: A Meta-Analytic Examination of Optimism and Hope. Personality and Individual Differences, 54, 821-827. https://doi.org/10.1016/j.paid.2012.12.004

APA (American Psychological Association) (2014). APA Dictionary of Statistics and Research Methods. American Psychological Association. 
Arslan, G., Yildirim, M., Karata, Z., Kabasakal, Z., \& Kilinç, M. (2020). Meaningful Living to Promote Complete Mental Health among University Students in the Context of the COVID-19 Pandemic. International Journal of Mental Health and Addiction, 1-13. https://doi.org/10.1007/s11469-020-00416-8

Bailey, T. C., Eng, W., Frisch, M. B., \& Snyder, C. R. (2007). Hope and Optimism as Related to life Satisfaction. The Journal of Positive Psychology, 2, 168-175.

https://doi.org/10.1080/17439760701409546

Blasco-Belled, A., Tejada-Gallardo, T., Torrelles-Nadal, C., \& Alsinet, C. (2020). The Costs of the COVID-19 on Subjective Well-Being: An Analysis of the Outbreak in Spain. Sustainability, 12, 6243. https://doi.org/10.3390/su12156243

Bronk, K. C., Hill, P. L., Lapsley, D. K., Talib, T. L., \& Finch, H. (2009). Purpose, Hope, and Life Satisfaction in Three Age Groups. Journal of Positive Psychology, 4, 500-510. https://doi.org/10.1080/17439760903271439

Brown, T. A. (2015). Confirmatory Factor Analysis for Applied Research. Guilford Publications.

Carver, C. S., \& Scheier, M. F. (1998). On the Self-Regulation Of Behavior. Cambridge University Press. https://doi.org/10.1017/CBO9781139174794

Carver, C. S., Scheier, M. F., \& Segerstrom, S. C. (2010). Optimism. Clinical Psychology Review, 30, 879-889. https://doi.org/10.1016/j.cpr.2010.01.006

Chang, E.C., Chang, O. D., Li, M., Xi, Z., Liu, Y., Zhang, X. et al. (2019). Positive Emotions, Hope, and Life Satisfaction in Chinese Adults: A Test of the Broaden-and-Build Model in Accounting for Subjective Well-Being in Chinese College Students. The Journal of Positive Psychology, 14, 829-835. https://doi.org/10.1080/17439760.2019.1579358

Cheavens, J., \& Gum, C. (2000). Gray Power: Hope for the Ages. In C. R. Snyder (Ed.), Handbook of Hope: Theory, Measures, and Applications (pp. 201-221). Academic Press. https://doi.org/10.1016/B978-012654050-5/50013-0

Chen, F. F. (2007). Sensitivity of Goodness of Fit Indexes to Lack of Measurement Invariance. Structural Equation Modeling: A Multidisciplinary Journal, 14, 464-504. https://doi.org/10.1080/10705510701301834

Cheung, G. W., \& Rensvold, R. B. (2002). Evaluating Goodness-of-Fit Indexes for Testing Measurement Invariance. Structural Equation Modeling, 9, 233-255. https://doi.org/10.1207/S15328007SEM0902 5

Compton, W. C., Smith, M. L., Cornish, K. A., \& Qualls, D. L. (1996). Factor Structure of Mental Health Measures. Journal of Personality and Social Psychology, 71, 406-413. https://doi.org/10.1037/0022-3514.71.2.406

Datu, J. A. D., \& King, R. B. (2016). Prioritizing Positivity Optimizes Positive Emotions and Life Satisfaction: A Three-Wave Longitudinal Study. Personality and Individual Differences, 96, 111-114. https://doi.org/10.1016/j.paid.2016.02.069

DeVellis, R. F. (2017). Scale Development: Theory and Applications (4th ed.). Sage.

Diener, E., Emmons, R. A., Larsen, R. J., \& Griffin, S. (1985). The Satisfaction with Life Scale. Journal of Personality Assessment, 49, 71-75. https://doi.org/10.1207/s15327752jpa4901 13

Diener, E., Suh, E. M., Lucas, R. E., \& Smith, H. L. (1999). Subjective Well-Being: Three Decades of Progress. Psychological Bulletin, 125, 276-302.

https://doi.org/10.1037/0033-2909.125.2.276

Diener, E., Wirtz, D., Tov, W., Kim-Prieto, C., Choi, D. W., Oishi, S., \& Biswas-Diener, R. (2010). New Well-Being Measures: Short Scales to Assess Flourishing and Positive and 
Negative Feelings. Social Indicators Research, 97, 143-156.

https://doi.org/10.1007/s11205-009-9493-y

Edwards, L. M. (2009). Hope. In S. Lopez (Ed.), The Encyclopedia of Positive Psychology (pp. 487-492). Blackwell.

Emmons, R. A. (1986). Personal Strivings: An Approach to Personality and Subjective Wellbeing. Journal of Personality and Social Psychology, 51, 1058-1068. https://doi.org/10.1037/0022-3514.51.5.1058

Feldman, D., \& Snyder, C. R. (1999). The Relationship of Dispositional Hope to Indices of Meaning: Does Hope Drive Meaning? Unpublished Manuscript, University of Kansas.

Fiorillo, A., \& Gorwood, P. (2020). The Consequences of the COVID-19 Pandemic on Mental Health and Implications for Clinical Practice. European Psychiatry, 63, e32. https://doi.org/10.1192/j.eurpsy.2020.35

Fornell, C., \& Larcker, D. F. (1981). Structural Equation Models with Unobservable Variables and Measurement Error: Algebra and Statistics. Journal of Marketing Research, 18, 382-388. https://doi.org/10.1177/002224378101800313

Fredrickson, B. (2001) The Role of Positive Emotions in Positive Psychology-The Broaden-and-Build Theory of Positive Emotions. American Psychologist, 56, 218-226. https://doi.org/10.1037/0003-066X.56.3.218

Fredrickson, B. L. (2005). The Broaden-and-Build Theory of Positive Emotions. In F. A. Huppert, N. Baylis, \& B. Keverne (Eds.), The Science of Well-Being (pp. 217-238). Oxford University Press. https://doi.org/10.1093/acprof:oso/9780198567523.003.0008

Fredrickson, B. L. (2013). Positive Emotions Broaden and Build. In P. Devine, \& A. Plant (Eds.), Advances in Experimental Social Psychology (Vol. 47, pp. 1-53). Academic Press. https://doi.org/10.1016/B978-0-12-407236-7.00001-2

Fredrickson, B. L., Cohn, M. A., Coffey, K. A., Pek, J., \& Finkel, S. M. (2008). Open Hearts Build Lives: Positive Emotions, Induced through Loving-Kindness Meditation, Build Consequential Personal Resources. Journal of Personality and Social Psychology, 95, 1045-1062. https://doi.org/10.1037/a0013262

Gallagher, M. W. (2009). Well-Being. In S. Lopez (Ed.), The Encyclopedia of Positive Psychology (pp. 1030-1034). Blackwell.

Greenstone, M., \& Nigam, V. (2020). Does Social Distancing Matter? University of Chicago, Becker Friedman Institute for Economics Working Paper No. 2020-26. https://doi.org/10.2139/ssrn.3561244

Hair J., Hult, G. T. M., Ringle, C., \& Sarstedt, M. (2014). A Primer on Partial Least Squares Structural Equation Modeling (PLS-SEM). SAGE Publications.

Hair, J., Black, W., Babin, B., \& Anderson, R. (2010). Multivariate Data Analysis (7th ed.). Prentice-Hall, Inc.

Hamid, A. Sami, W., \& Sidek, M. (2017). Discriminant Validity Assessment: Use of Fornell \& Larcker Criterion versus HTMT Criterion. Journal of Physics: Conference Series, 890, Article ID: 012163. https://doi.org/10.1088/1742-6596/890/1/012163

Henseler, J., Ringle, C. M., \& Sarstedt, M. (2015). A New Criterion for Assessing Discriminant Validity in Variance-Based Structural Equation Modeling. Journal of the Academy of Marketing Science, 43, 115-135. https://doi.org/10.1007/s11747-014-0403-8

Hirschi, A., Abessolo, M., \& Froidevaux, A. (2015). Hope as a Resource for Career Exploration: Examining Incremental and Cross-Lagged Effects. Journal of Vocational Behavior, 86, 38-47. https://doi.org/10.1016/j.jvb.2014.10.006 
Holmes, E. A. et al. (2020). Multidisciplinary Research Priorities for the COVID-19 Pandemic: A Call for Action for Mental Health Science. Lancet Psychiatry, 7, 547-560. https://doi.org/10.1016/S2215-0366(20)30168-1

Hu, L. T., \& Bentler, P. M. (1999). Cutoff Criteria for Fit Indexes in Covariance Structure Analysis: Conventional Criteria versus New Alternatives. Structural Equation Modeling, 6, 1-55. https://doi.org/10.1080/10705519909540118

Jackson, P., \& Agunwamba, C. (1977). Lower Bounds for the Reliability of the Total Score on a Test Composed of Nonhomogeneous Items: I: Algebraic Lower Bounds. Psychometrika, 42, 567-578. https://doi.org/10.1007/BF02295979

Ju, H., Shin, J. W., Kim, C., Hyun, M., \& Park, J. (2013). Mediational Effect of Meaning in Life on the Relationship between Optimism and Well-Being in Community Elderly. Archives of Gerontology and Geriatrics, 56, 309-313. https://doi.org/10.1016/j.archger.2012.08.008

Kapikiran, N. A. (2012). Positive and Negative Affectivity as Mediator and Moderator of the Relationship between Optimism and Life Satisfaction in Turkish University Students. Social Indicators Research, 106, 333-345.

https://doi.org/10.1007/s11205-011-9807-8

King, L. A., Hicks, J. A., Krull, J. L., \& Del Gaiso, A. K. (2006). Positive Affect and the Experience of Meaning in Life. Journal of Personality and Social Psychology, 90, 179-196. https://doi.org/10.1037/0022-3514.90.1.179

Kline, R. B. (2011). Principles and Practice of Structural Equation Modeling (3rd ed.). The Guilford Press.

Kline, R. B. (2016). Principles and Practice of Structural Equation Modeling: Methodology in the Social Sciences (4th ed.). The Guilford Press.

Kline, R. B. (2020). Becoming a Behavioral Science Researcher (2nd ed.). The Guilford Press.

Kwok, S. Y. C. L., \& Fang, S. (2021). A Cross-Lagged Panel Study Examining the Reciprocal Relationships between Positive Emotions, Meaning, Strengths Use and Study Engagement in Primary School Students. Journal of Happiness Studies, 22, 1033-1053. https://doi.org/10.1007/s10902-020-00262-4

Kyriazos, T. (2017). Reliability of Psychometric Instruments. In M. Galanakis, C. Pezirkianidis, \& A. Stalikas (Eds.), Basic Aspects of Psychometrics (p. 85-126). Topos.

Kyriazos, T. A. (2018a). Applied Psychometrics: Writing-Up a Factor Analysis Construct Validation Study with Examples. Psychology, 9, 2503-2530. https://doi.org/10.4236/psych.2018.911144

Kyriazos, T. A. (2018b). Applied Psychometrics: The Application of CFA to Multitrait-Multimethod Matrices (CFA-MTMM). Psychology, 9, 2625-2648.

https://doi.org/10.4236/psych.2018.912150

Kyriazos, T. A. (2019). Applied Psychometrics: The Modeling Possibilities of Multilevel Confirmatory Factor Analysis (MLV CFA). Psychology, 10, 777-798. https://doi.org/10.4236/psych.2019.106051

Kyriazos, T. A., \& Stalikas, A. (2018). Positive Parenting or Positive Psychology Parenting? Towards a Conceptual Framework of Positive Psychology Parenting. Psychology, 9, 1761-1788. https://doi.org/10.4236/psych.2018.97104

Kyriazos, T. A., \& Stalikas, A. (2019a). Alabama Parenting Questionnaire-Short Form (APQ-9): Evidencing Construct Validity with Factor Analysis, CFA MTMM and Measurement Invariance in a Greek Sample. Psychology, 10, 1790-1817.

https://doi.org/10.4236/psych.2019.1012117 
Kyriazos, T. A., \& Stalikas, A. (2019b). Nicomachus-Positive Parenting (NPP): Development and Initial Validation of a Parenting Questionnaire within the Positive Psychology Framework. Psychology, 10, 2115-2165.

https://doi.org/10.4236/psych.2019.1015136

Kyriazos, T. A., Stalikas, A., Prassa, K., \& Yotsidi, V. (2018). A 3-Faced Construct Validation and a Bifactor Subjective Well-Being Model Using the Scale of Positive and Negative Experience, Greek Version. Psychology, 9, 1143-1175.

https://doi.org/10.4236/psych.2018.95071

Kyriazos, T. A., Stalikas, A., Prassa, K., Galanakis, M., Flora, K., \& Chatzilia, V. (2018). The Flow Short Scale (FSS) Dimensionality and What MIMIC Shows on Heterogeneity and Invariance. Psychology, 9, 1357-1382. https://doi.org/10.4236/psych.2018.96083

Kyriazos, T. A., Stalikas, A., Prassa, K., Yotsidi, V., Galanakis, M., \& Pezirkianidis, C. (2018). Validation of the Flourishing Scale (FS), Greek Version and Evaluation of Two Well-Being Models. Psychology, 9, 1789-1813. https://doi.org/10.4236/psych.2018.97105

Kyriazos, T., Galanakis, M., Karakasidou, E., \& Stalikas, A. (2021). Early COVID-19 Quarantine: A Machine Learning Approach to Model What Differentiated the Top 25\% Well-Being Scorers. Personality and Individual Differences, 181, Article ID: 110980. https://doi.org/10.1016/j.paid.2021.110980

Lazarus, R. (1991). Emotion and Adaptation. Oxford University Press.

Leung, B. W., Moneta, G. B., \& Mcbride-Chang, C. (2005). Think Positively and Feel Positively: Optimism and Life Satisfaction in Late Life. International Journal of Aging and Human Development, 61, 335-365. https://doi.org/10.2190/FQTB-EBAJ-H9WP-LMYA

Li, M., Gu, Y., Ma, Y., Liu, M., \& Tang, X. (2021). Positive Emotions, Hope, and Life Satisfaction in Chinese College Students: How Useful Is the Broaden-and-Build Model in Studying Well-Being in Victims of Intimate Partner Violence? Journal of Interpersonal Violence, 1-10. https://doi.org/10.1177/08862605211005131

MacCallum, R. C., Browne, M. W., \& Sugawara, H. M. (1996). Power Analysis and Determination of Sample Size for Covariance Structure Modeling. Psychological Methods, 1, 130-149. https://doi.org/10.1037/1082-989X.1.2.130

Mair, P. (2018). Modern Psychometrics with R. Springer International. https://doi.org/10.1007/978-3-319-93177-7

McDonald, R. P. (1999). Test Theory: A Unified Treatment. Erlbaum.

O'Connor, R. C. et al. (2020). Mental Health and Well-Being during the COVID-19 Pandemic: Longitudinal Analyses of Adults in the UK COVID-19 Mental Health \& Wellbeing Study. The British Journal of Psychiatry, 218, 326-333.

https://doi.org/10.1192/bjp.2020.212

Oliver, A., Tomas, J. M., \& Montoro-Rodriguez, J. (2017). Dispositional Hope and Life Satisfaction among Older Adults Attending Lifelong Learning Programs. Archives of Gerontology and Geriatrics, 72, 80-85. https://doi.org/10.1016/j.archger.2017.05.008

Pallini, S., Milioni, M., Laghi, F., \& Vecchio, G. M. (2018). The Ant and the Grasshopper: Adolescents' Time Perspective, Satisfaction with Life and the Mediating Role of Hope. Journal of Happiness Studies, 19, 351-364. https://doi.org/10.1007/s10902-016-9821-2

Pavot, W. (2018). The Cornerstone of Research on Subjective Well-Being: Valid Assessment Methodology. In E. Diener, S. Oishi, \& L. Tay (Eds.), Handbook of Well-Being (pp. 1-11). DEF Publishers.

Peterson, C., \& Seligman, M. E. P. (2004). Character Strengths and Virtues. Oxford University Press. 
R Development Core Team (2021). R: A Language and Environment for Statistical Computing. R Foundation for Statistical Computing.

Ryff, C. D. (1989) Happiness Is Everything, or Is It? Explorations on the Meaning of Psychological Wellbeing. Journal of Personality and Social Psychology, 57, 1069-1081. https://doi.org/10.1037/0022-3514.57.6.1069

Scheier, M. F., \& Carver, C. S. (1985). Optimism, Coping, and Health: Assessment and Implications of Generalized Outcome Expectancies. Health Psychology, 4, 219-247. https://doi.org/10.1037/0278-6133.4.3.219

Scheier, M. F., \& Carver, C. S. (1992). Effects of Optimism on Psychological and Physical Wellbeing: Theoretical Overview and Empirical Update. Cognitive Therapy and Research, 16, 201-228. https://doi.org/10.1007/BF01173489

Scheier, M. F., Carver, C. S., \& Bridges, M. W. (1994). Distinguishing Optimism from Neuroticism (and Trait Anxiety, Self-Mastery, and Self-Esteem): A Re-Evaluation of the Life Orientation Test. Journal of Personality and Social Psychology, 67, 1063-1078. https://doi.org/10.1037/0022-3514.67.6.1063

Seligman, M. E. (2006). Learned Optimism: How to Change Your Mind and Your Life (3rd ed.). Vintage Books.

Snyder, C. R. (2000). Handbook of Hope: Theory, Measures, and Applications. Academic Press.

Snyder, C. R., Harris, C., Anderson, J. R., Holleran, S. A., Irving, L. M., Sigmon, S. T., Yoshinobu, L., Gibb, J., Langelle, C., \& Harney, P. (1991). The Will and the Ways: Development and Validation of an Individual-Differences Measure of Hope. Journal of Personality and Social Psychology, 60, 570-585. https://doi.org/10.1037/0022-3514.60.4.570

Snyder, C. R., Sympson, S., Michael, S. T., \& Cheavens, J. (2000). The Optimism and Hope Constructs: Variants on a Positive Expectancy Theme. In E. C. Chang (Ed.), Optimism and Pessimism (pp. 103-124). American Psychological Association.

Stalikas, A., \& Kyriazos, T. (2019). Research Methods and Statistics Using R. Topos.

Stalikas, A., Kyriazos, T. A., Yotsidi, V., \& Prassa, K. (2018). Using Bifactor EFA, Bifactor CFA and Exploratory Structural Equation Modeling to Validate Factor Structure of the Meaning in Life Questionnaire, Greek Version. Psychology, 9, 348-371. https://doi.org/10.4236/psych.2018.93022

Steger, M. F. (2009a). Meaning in life. In S. J. Lopez (Ed.) Oxford Handbook of Positive Psychology (pp. 679-687). Oxford University Press. https://doi.org/10.1093/oxfordhb/9780195187243.013.0064

Steger, M. F. (2009b). Meaning. In S. Lopez (Ed.), The Encyclopedia of Positive Psychology (pp. 605-610). Blackwell.

Steger, M. F. (2012). Experiencing Meaning in Life: Optimal Functioning at the Nexus of Spirituality, Psychopathology, and Well-Being. In P. T. P. Wong, \& P. S. Fry (Eds.) The Human Quest for Meaning (pp. 165-184). Routledge.

Steger, M. F., \& Frazier, P. (2005). Meaning in Life: One Link in the Chain from Religion to Well-Being. Journal of Counseling Psychology, 52, 574-582.

https://doi.org/10.1037/0022-0167.52.4.574

Steger, M. F., Frazier, P., Oishi, S., \& Kaler, M. (2006). The Meaning in Life Questionnaire: Assessing the Presence of and Search for Meaning in Life. Journal of Counseling Psychology, 53, 80-93. https://doi.org/10.1037/0022-0167.53.1.80

Steger, M. F., Sheline, K., Merriman, L., \& Kashdan, T. B. (2013). Using the Science of Meaning to Invigorate Values-Congruent, Purpose-Driven Action. In T. B. Kashdan, \& 
J. V. Ciarrochi (Eds.), Mindfulness, Acceptance, and Positive Psychology: The Seven Foundations of Well-Being (pp. 256-266). Context Press.

Supervía, P. U., Bordás, S. B., \& Lorente, V. M. (2020). Exploring the Psychological Effects of Optimism on Life Satisfaction in Students: The Mediating Role of Goal Orientations. International Journal of Environmental Research and Public Health, 17, 7887. https://doi.org/10.3390/ijerph17217887

Trzebiński, J., Cabański, M., \& Czarnecka, J. Z. (2020). Reaction to the COVID-19 Pandemic: The Influence of Meaning in Life, Life Satisfaction, and Assumptions on World Orderliness and Positivity. Journal of Loss and Trauma, 25, 544-557. https://doi.org/10.1080/15325024.2020.1765098

Tugade, M. M., \& Fredrickson, B. L. (2004). Resilient Individuals Use Positive Emotions to Bounce Back from Negative Emotional Experiences. Journal of Personality and Social Psychology, 86, 320-333. https://doi.org/10.1037/0022-3514.86.2.320

Werts, C. E., Linn, R. L., \& Jöreskog, K. G. (1974). Intraclass Reliability Estimates: Testing Structural Assumptions. Educational and Psychological measurement, 34, 25-33. https://doi.org/10.1177/001316447403400104

WHO (World Health Organization) (2020). Mental Health and Psychosocial Considerations during the COVID-19 Outbreak. https://www.who.int/emergencies/diseases/novel-coronavirus-2019/

Yarcheski, A., \& Mahon, N. E. (2014). Meta-Analyses of Predictors of Hope in Adolescents. Western Journal of Nursing Research, 38, 345-368. https://doi.org/10.1177/0193945914559545

Yıldırım, M., \& Arslan, G. (2021). A Moderated Mediation Effect of Stress-Related Growth and Meaning in Life in the Association between Coronavirus Suffering and Satisfaction with Life: Development of the Stress-Related Growth Measure. Frontiers in Psychology, 12, Article ID: 648236. https://doi.org/10.3389/fpsyg.2021.648236

Zacher, H., \& Rudolph, C. W. (2021). Individual Differences and Changes in Subjective Wellbeing during the Early Stages of the COVID-19 Pandemic. American Psychologist, 76, 50-62. https://doi.org/10.1037/amp0000702 


\section{Appendix}

Table A1. Multivariate normality tests, outliers and critical value for mahalanobis distance $\left(\chi^{2}\right)$, for each measure of the study and for the measurement model $(\mathrm{N}=759)$.

\begin{tabular}{|c|c|c|c|c|c|c|c|}
\hline \multirow{2}{*}{ Latent Variables } & \multicolumn{7}{|c|}{ Multivariate Normality Tests } \\
\hline & Outliers & $D^{2}$ Critical Value $(d f)^{*}$ & Mardia's Skew ${ }^{\star}$ & Mardia's Kurtosis* & Doornik-Hansen $(d f)^{\star}$ & Energy Test* & Henze-Zirkler \\
\hline SPANE-8 $(k=8)$ & 10 & $26.13(8)$ & 417.01 & 24.25 & $78.92(16)$ & 6.39 & 2.52 \\
\hline $\operatorname{MLQ}(k=10)$ & 0 & $29.59(10)$ & 2365.81 & 59.27 & $896.17(20)$ & 21.55 & 5.78 \\
\hline AHS $(k=8)$ & 29 & $26.13(8)$ & 1397.50 & 52.18 & $556.44(16)$ & 17.80 & 4.65 \\
\hline LOT-R $(k=6)$ & 12 & $22.46(6)$ & 495.31 & 19.37 & $208.17(12)$ & 7.34 & 3.37 \\
\hline SWLS $(k=5)$ & 13 & $20.52(5)$ & 448.83 & 24.24 & $111.44(10)$ & 13.10 & 5.67 \\
\hline $\begin{array}{c}\text { Measurement Model } \\
\quad(k=21)^{\mathrm{a}}\end{array}$ & 40 & $46.80(21)$ & 6648.90 & 80.67 & $462.114(42)$ & 2472.32 & 1.23 \\
\hline
\end{tabular}

${ }^{*} p<0.001$. ${ }^{a}$ The latent variables of the measurement model were SPANE-8 P (SPANE-8 Positive), MLQ-P (Meaning in Life Presence), AHS-A (Adult Hope Scale Agency), LOT-R O (Life Orientation Test-Revised, Optimism) and SWLS (Satisfaction with life Scale).

Table A2. Goodness of fit for the CFA to verify the factor structure of all study measures $(N=759)$.

\begin{tabular}{cccccccccccc}
\hline \multirow{2}{*}{$\begin{array}{c}\text { Models of Study } \\
\text { Measures }\end{array}$} & \multicolumn{1}{c}{ RMSEA 90\%CI } \\
\cline { 2 - 12 } & $x^{2}$ & $d f$ & $p$ & CFI & TLI & RMSEA & Lower & Upper & SRMR & Loadings Range & Inter-factor Correlation \\
\hline SPANE-8: 2-factor & 40.17 & 19 & 0.003 & 0.990 & 0.985 & 0.038 & 0.024 & 0.052 & 0.027 & $0.548-0.859$ & -0.761 \\
MLQ: 2-factor & 225.84 & 34 & 0.000 & 0.925 & 0.901 & 0.086 & 0.077 & 0.095 & 0.080 & $0.628-0.905$ & 0.221 \\
LOT-R: 2-factor ${ }^{\text {a }}$ & 38.87 & 8 & 0.000 & 0.966 & 0.936 & 0.071 & 0.024 & 0.052 & 0.037 & $0.468-0.804$ & 0.749 \\
AHS: 2-factor & 142.84 & 19 & 0.000 & 0.935 & 0.904 & 0.093 & 0.081 & 0.104 & 0.048 & $0.687-0.826$ & 0.883 \\
SWLS: Single factor & 20.75 & 5 & 0.001 & 0.986 & 0.972 & 0.064 & 0.043 & 0.088 & 0.024 & $0618-0.879$ & - \\
\hline
\end{tabular}

Note . Estimator $=$ MLR. $\mathrm{df}=$ Degrees of freedom; CFI = Comparative Fit Index; TLI = Tucker-Lewis index; RMSEA = Root Mean Square Error of Approximation; $\mathrm{CI}=$ Confidence Interval; SRMR $=$ Standardized Root Mean Square Residual. AIC = Akaike Information Criterion, BIC = Bayesian Information Criterion. ${ }^{\text {a }}$ LOT-R Optimism $=$ items 1, 4, 10, LOT-R Pessimism $=$ items 3, 7, 9 (Recoded).

Table A3. Standardized loadings $(\lambda)$, and R squared for the SEM measurement model $(N=759)$.

\begin{tabular}{|c|c|c|c|c|c|c|c|}
\hline Latent Variables & Measured Variables & $\lambda^{*}$ & $\mathrm{R}^{2}$ & Latent Variables & Measured Variables & $\lambda^{*}$ & $\mathrm{R}^{2}$ \\
\hline \multirow{4}{*}{ SPANE-8 P } & SPANE-8 P 2 & 0.839 & 0.705 & LOT-R O & LOT-R 1 & 0.597 & 0.357 \\
\hline & SPANE-8 P 3 & 0.850 & 0.723 & & LOT-R 4 & 0.821 & 0.675 \\
\hline & SPANE-8 P 6 & 0.757 & 0.574 & & LOT-R 10 & 0.738 & 0.544 \\
\hline & SPANE-8 P 8 & 0.780 & 0.609 & SWLS & SWLS 1 & 0.846 & 0.716 \\
\hline \multirow{5}{*}{ MLQ-P } & MLQ-P 1 & 0.755 & 0.571 & & SWLS 2 & 0.730 & 0.533 \\
\hline & MLQ-P 4 & 0.830 & 0.689 & & SWLS 3 & 0.867 & 0.751 \\
\hline & MLQ-P 5 & 0.845 & 0.714 & & SWLS 4 & 0.764 & 0.583 \\
\hline & MLQ-P 6 & 0.901 & 0.811 & & SWLS 5 & 0.635 & 0.403 \\
\hline & MLQ-P 9 & 0.637 & 0.406 & & & & \\
\hline \multirow{4}{*}{ AHS-A } & AHS-A 2 & 0.747 & 0.558 & & & & \\
\hline & AHS-A 9 & 0.624 & 0.389 & & & & \\
\hline & AHS-A 10 & 0.844 & 0.713 & & & & \\
\hline & AHS-A 12 & 0.751 & 0.564 & & & & \\
\hline
\end{tabular}

${ }^{*} p<0.001$. Note. Estimator $=$ MLR. SPANE-8 P = SPANE-8 Positive, MLQ-P = Meaning in Life Presence, AHS-A = Adult Hope Scale Agency, LOT-R O = Life Orientation Test-Revised Optimism, and SWLS = Satisfaction with life Scale. 

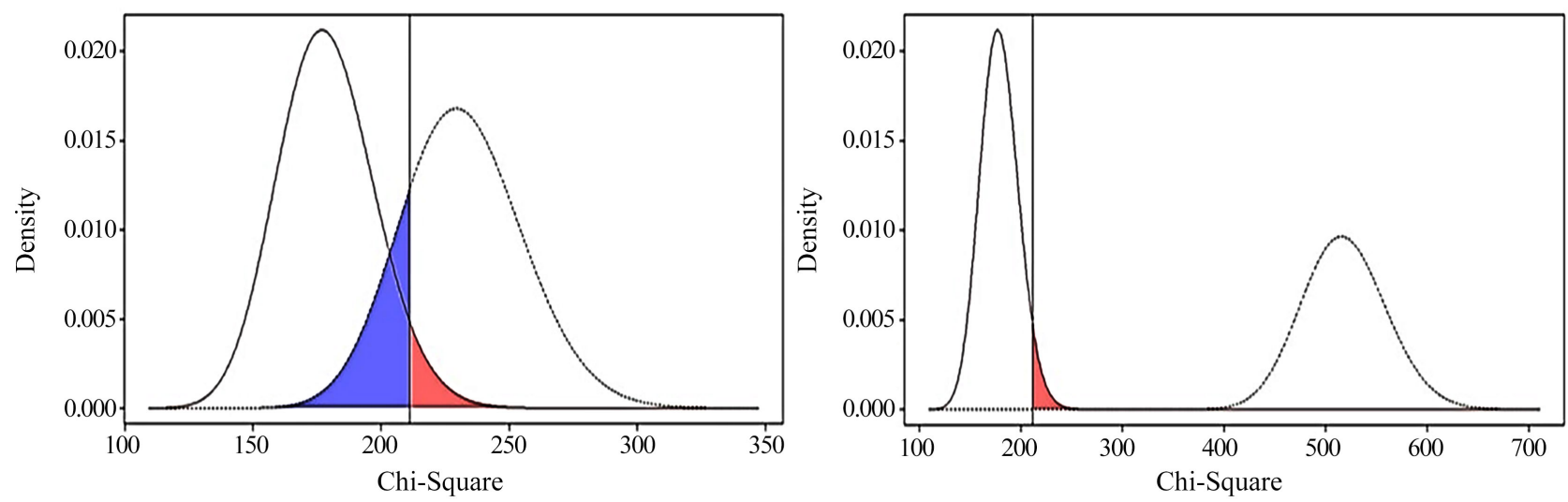

Figure A1. A priori (Left) and Post-hoc (Right) power analysis based on RMSEA for the structural SEM model.

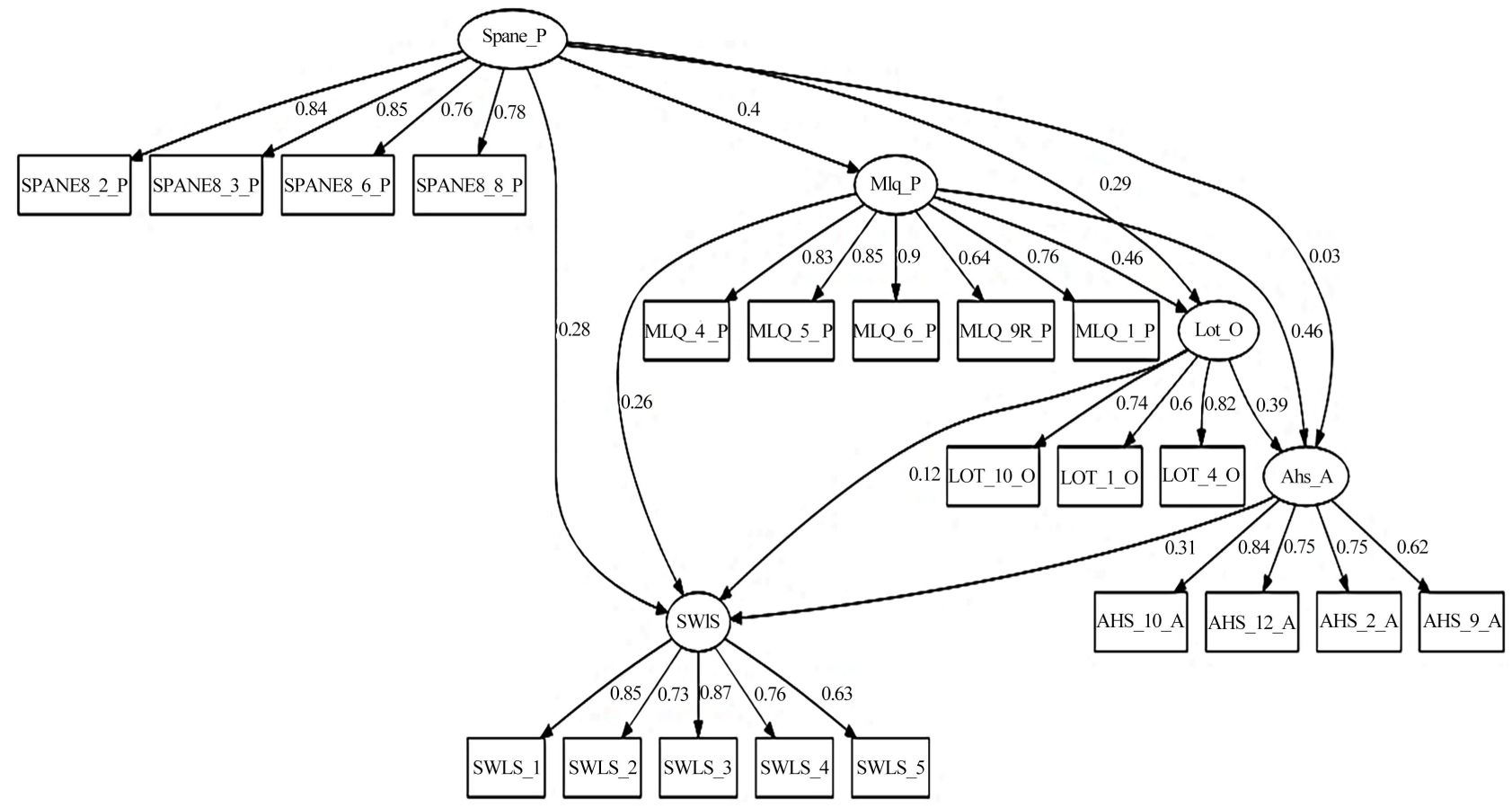

Figure A2. The path diagram of the full SEM model (direct standardized path coefficients. Positive emotions (SPANE-8 P), presence of life meaning (MLQ-P), optimism (LOT-R O), and hope agency (AHS-A) explained 61.5\% of the variance in life satisfaction (SWLS). 